\title{
Karawitan Pakeliran Gaya Kedu Bagelen
}

\author{
Suhardjono ${ }^{1}$ dan Trikoyo \\ Jurusan Karawitan, Fakultas Seni Pertunjukan, Institut Seni Indonesia Yogyakarta
}

\begin{abstract}
ABSTRAK
Karawitan pakeliran gaya Kedu Bagelen merupakan salah satu gaya Kedu yang berkembang di wilayah Purworejo. Fungsi karawitan tertuang dalam sajian-sajian gending yang disesuaikan dengan adegan-adegan pakeliran. Karawitan berfungsi membantu menciptakan suasana adegan dan karakter tokoh wayang. Struktur penyajian gending terdiri dari gending Pengawe-awe yang berbentuk ladrang dilanjutkan dengan bagian gending Gagalan berbentuk ketuk 2 kerep minggah ketuk 4 kerep. Gending tersebut laras slendro patet sanga. Bagian gending pakeliran terangkai dari awal pertunjukan atau bedhol kayon sampai akhir pertunjukan atau tancep kayon. Metode deskriptif analisis digunakan dalam penelitian ini untuk mengungkap penyajian gending-gending dalam karawitan pakeliran gaya Kedu Bagelen. Ciri khas yang membedakan dengan karawitan pakeliran yang lain terletak pada garap balungan gending.

Kata kunci: karawitan, pakeliran, wayang Kedu, Bagelen
\end{abstract}

\section{ABSTRACT}

Gammelan Music for Wayang of Kedu Bagelan Style. The Javanese musical functions are expressed in gending instruments adjusted into pakeliran scenes; the instrument helps in creating the scene atmosphere and puppet characters. Kedu Bagelen musical style has its own characteristics which are different from other styles. The structure of gending instrument presents gending Pengawe-awe in ladrang notation followed by parts of gending Gagalan which consists of 2 kerep minggah rhythms and 4 kerep rhythms. Gending instrument applies the notation of laras slendro patet sanga. The series of gending pakeliran are sequenced from bedhol kayon / opening scene until tancep kayon/ending scene of the puppet show. The research applied descriptive method of analysis in revealing the presentation of gending in Kedu Bagelen pakeliran musical style. There were several characteristics that distinguished it from other pakeliran music. The most prominent specification of pakeliran work on Bagelen Kedu musical styles lied on the work of balungan gending

Keywords: gamelan music, wayang performance, Kedu Bagelen

\section{Pendahuluan}

Pertunjukan wayang atau pakeliran di setiap wilayah di Jawa memiliki ciri-ciri khusus yang oleh masyarakat luas biasa disebut dengan istilah gaya, seperti pakeliran gaya Yogyakarta, Surakarta, Jawa Timur, Banyumas, Pesisiran dan Kedu. Gaya dalam pakeliran merupakan suatu ciri khas yang membedakan identitas (wayang) dari satu daerah dengan daerah yang lain. Gayagaya yang ada, akan memperlihatkan perbedaan unsur-unsur pakeliran suatu daerah tertentu. Perbedaan tersebut dapat dilihat dari keseluruhan aspek seni pertunjukan, yakni dari aspek bentuk boneka wayangnya (wanda), segi tata pakeliran atau urutan alur, musik pengiring vokal dan instrumennya seperti bentuk, isi lagu, kandha, sulukan, pocapan dan janturan (Kayam, 2001:81).

Di antara beberapa gaya pakeliran di Jawa terdapat pakeliran gaya Kedu. Kedu merupakan salah satu wilayah di Jawa Tengah yang memiliki gaya atau ciri khas khusus dalam pakeliran. Kedu adalah wilayah bekas karesidenan peninggalan Belanda di Jawa Tengah yang terdiri dari daerah Wonosobo, Temanggung, Magelang, dan Bagelen atau Purworejo. Setiap daerah tersebut memiliki banyak perbedaan mengenai berbagai hal yang berhubungan dengan pakeliran. Sejalan dengan luas wilayah persebaran budayanya, Kedu memiliki banyak corak gaya pakeliran yang berbeda dalam lingkup satu wilayah.

Pakeliran Kedu memiliki beberapa gaya di dalamnya yaitu gaya Kedu Wonosobo, Kedu Temanggung, Kedu Magelang dan Kedu Bagelen atau Purworejo. Pakeliran gaya Kedu Bagelen atau Purworejo memiliki spesifikasi tersendiri yang terdapat pada karawitan iringan, yaitu terlihat pada bentuk, struktur dan garap.

Berdasarkan hasil observasi di lapangan, pakeliran Kedu termasuk Kedu Bagelen memiliki spesifikasi atau ciri-ciri yang berbeda. Ciri-ciri

1 Alamat Korespondensi: Pogram Studi Seni Karawitan ISI Yogyakarta. Jalan Parangtritis KM. 6,5 Sewon Yogyakarta 55001. HP: 08122703725 e-mail: hardjono@isi.ac.id. 
tersebut terdapat pada bentuk wayang, balungan gending iringan, serta sajian karawitan iringannya (Purwoko, 2010:6). Spesifikasi garap karawitan iringan gaya Kedu Bagelen yang lainnya terletak pada pola ater-ater kendang. Susunan balungan gending banyak menggunakan pola balungan nglagu. Jumlah ketukan/sabetan dalam satu gatra balungan ada yang hanya terdiri dari dua ketukan atau dua sabetan balungan saja. Artinya, jika secara umum satu gatra berisi empat ketukan nada (sabetan), pada karawitan gaya Kedu Bagelen ditemui gatra yang hanya memiliki dua ketukan (sabetan) nada.

Saat ini karawitan pakeliran gaya Kedu Bagelen kurang berkembang dengan baik. Ini terlihat dengan semakin jarang dipentaskannya pakeliran gaya Kedu Bagelen dibandingkan dengan pertunjukan wayang gaya Surakarta dan Yogyakarta. Tidak diajarkannya iringan pakeliran gaya Bagelen pada generasi muda juga menjadi faktor penyebab kurang diketahuinya gaya Bagelen ini di tengah masyarakat luas.

\section{Pakeliran Gaya Kedu Bagelen}

Pakeliran gaya Kedu Bagelen merupakan salah satu di antara beberapa gaya pakeliran di wilayah Kedu. Seperti pakeliran gaya Kedu lainnya, gaya Bagelen dalam perkembangan dan pembelajarannya hanya dilakukan secara turun temurun. Salah satu contoh adalah seorang dalang gaya Bagelen Ki Sunarko (almarhum). Dalang ini mewarisi keahlian memainkan wayang gaya Bagelen dari ayahnya bernama Ki Darmo Setiko atau lebih dikenal dengan dalang Gethuk. Dalang lain yang menguasai pakeliran gaya Bagelen adalah Ki Sutarko dari Pacor Kutoarjo yang juga merupakan keponakan dari Ki Sunarko. Ki Sutarko dapat mempelajari gaya Bagelen juga dari almarhum Ki Sunarko. Satu dalang lagi yang menguasai pakeliran gaya Bagelen bernama Ki Hartono, merupakan seorang pemain kendang yang sejak muda sudah mengikuti pementasan $\mathrm{Ki}$ Sunarko. Oleh karena selalu mengiringi pakeliran gaya Kedu Bagelen, Ki Hartono akhirnya dapat menguasai garap pakeliran gaya Kedu Bagelen.

Perkembangan pakeliran gaya Kedu Bagelen sangat terbatas dikarenakan tidak adanya pakem atau acuan yang digunakan. Sarana pembelajaran kepada generasi penerus hanya dilakukan secara turun temurun dan lisan. Berbeda dengan pakeliran gaya Surakarta dan Yogyakarta, awalnya berkembang di lingkungan kraton, sehingga oleh para seniman kraton dibuatlah suatu pakem atau acuan baku mengenai pakeliran. Pakem inilah kemudian disebarkan di masyarakat umum sehingga kedua gaya ini lebih dikenal oleh masyarakat umum (Murtiyoso, 2004:18).

Pertunjukan pakeliran gaya Kedu Bagelen di masyarakat sangat jarang dilakukan disebabkan terbatasnya dalang yang menguasai pakeliran gaya Bagelen. Faktor lain adalah tidak diminati oleh masyarakat. Masyarakat cenderung lebih menyukai gaya Yogyakarta dan Surakarta yang dianggap mampu mengikuti perkembangan jaman. Kedua gaya ini mudah dipelajari masyarakat karena banyak buku-buku pakem yang beredar serta adanya lembaga formal atau kelompok-kelompok yang mengajarkan pakeliran gaya Yogyakarta dan Surakarta.

Berkurangnya minat masyarakat terhadap pakeliran Gaya Kedu Bagelen mengakibatkan semakin minimnya pertunjukan serta jumlah seniman. Berdasarkan hasil observasi di lapangan tercatat bahwa dalang wayang kulit gaya Bagelen hanya ada dua yaitu Ki Sutarko Hadi Wacono dari Pacor Kutoarjo dan Ki Hartono dari Klepu. Untuk grup karawitan Bagelen hanya ada satu grup yang terdapat di Desa Klepu Kecamatan Butuh.

\section{Karawitan Pakeliran Gaya Kedu Bagelen}

Karawitan memiliki arti sebuah sajian musik dengan media gamelan sebagai alat dan berlaras pentatonis. Karawitan juga merupakan sebuah sajian musik yang mampu memunculkan berbagai suasana Sutrisno, 1976:6). Sebuah pertunjukan wayang kulit tidak bisa lepas dari sajian karawitan (Soetarno, 2002:166). Sebagai partner dalam pakeliran, karawitan memiliki fungsi sebagai iringan wayang yang harus dapat menggambarkan dan menguatkan tokoh wayang (Yudoyono, 1983:15-16). Karawitan pakeliran memiliki hubungan khusus dalam menciptakan suasana tertentu dalam setiap adegan. Karawitan pakeliran dalam sajiannya tidak hanya sebatas sajian musik gamelan saja, melainkan juga mencakup sajian vokal.

Karawitan pakeliran memiliki peranan penting dalam wayang yaitu membantu menciptakan suasana adegan sesuai dengan alur cerita wayang yang disampaikan. Menurut Sutrisno, suasana 
yang dimunculkan dari sajian karawitan pakeliran sangat beragam, di antaranya menciptakan suasana khidmat, agung, sedih, senang atau sigrak dan nges (Sutrisno, 1976:6). Dengan demikian, karawitan pakeliran tidak hanya sebagai sajian musik pengiring pertunjukan wayang kulit saja, tetapi juga merupakan satu kesatuan sajian yang utuh antara wayang dan karawitan yang tidak dapat dipisahkan.

Gamelan yang digunakan sebagai pengiring sajian wayang gaya Bagelen awalnya adalah seperangkat gamelan laras slendro. Ricikan gamelan yang digunakan dalam pakeliran gaya Kedu Bagelen di antaranya: kendang batang, gender barung, slentem, gambang, bonang barung, bonang penerus, ketuk, kenong, kempul, gong, demung, saron, peking dan siter. Seiring dengan perkembangan jaman, selain laras slendro, karawitan pakeliran gaya Kedu Bagelen juga telah menggunakan gamelan berlaras pelog. Jadi pakeliran gaya Bagelen sekarang telah menggunakan seperangkat Gamelan Ageng. Hal ini juga karena didukung adanya sumber daya manusia khususnya para seniman muda.

\section{Patet dalam Karawitan Pakeliran Gaya Kedu Bagelen}

Patet merupakan salah satu hal penting yang harus dipertimbangkan oleh seorang dalang dan pengrawit ketika memainkan wayang, menafsir gending, serta menentukan hubungan nada dalam membentuk sebuah kalimat lagu. Pengertian lain dari patet adalah urusan rasa musikal yang berupa rasa seleh, sedangkan rasa seleh merupakan rasa berhenti kalimat lagu dalam sajian karawitan (Hastanto, 2009:16).

Karawitan iringan pakeliran gaya Bagelen menggunakan tiga pembagian patet seperti pada pakeliran gaya Yogyakarta dan Surakarta, yaitu patet nem, patet sanga dan patet manyura. Pembagian patet juga merupakan tanda atau pemilah pembagian waktu atau dihubungkan dengan periode waktu dalam wayang kulit dengan jam-jam tertentu (Yudoyono, 1983:54. Patet nem berlangsung dari pukul 21.00-24.00. Patet sanga akan dimulai dari pukul 24.00-pukul 03.00. Sementara untuk patet manyura dimulai dari pukul 03.00 sampai dengan pukul 06.00. Pembagian patet dalam pakeliran di dalamnya terdapat beberapa bagian adegan serta memiliki gending-gending iringan yang sesuai berdasar patet gending itu sendiri (Purwadi, 2006:41-45).

Berikut adalah pembagian patet beserta pembagian adegan dalam sajian pakeliran gaya Kedu Bagelen:

\section{Patet Nem}

Patet nem merupakan pembagian waktu yang pertama dalam sajian pertunjukan wayang. Patet ini periode waktunya antara pukul 21.00 sampai dengan pukul 24.00. Adegan-adegan yang terdapat dalam patet nem adalah Jejer I sampai Jejer III.

\section{Jejer I}

Bagian ini merupakan awal pertunjukan wayang yang ditandai dengan bedhol kayon. Adegan ini memiliki arti dimulainya kehidupan dalam dunia pakeliran. Setelah bedhol kayon dilanjutkan dengan adegan suatu tempat, biasanya sebuah negara, kahyangan, pertapaan atau tempat lainnya. Pada bagian ini merupakan bagian awal cerita dan mulai muncul permasalahan. Dalam pakeliran gaya Bagelen, bagian ini berisi uraian yang sangat panjang, yaitu menceritakan sebuah tempat atau kerajaan beserta rakyatnya yang dalam penyampaiannya disampaikan dalang melalui janturan (Purwoko, 2010:25. Bagian jejer I terdapat beberapa adegan meliputi adegan kedhaton, paseban njawi dan budhalan .

\section{Jejer II}

Bagian ini menceritakan suatu tempat (negara, padepokan atau tempat lain) yang berbeda tetapi permasalahan yang muncul masih ada hubungan dengan masalah pada jejer $I$. Dalam jejer $I I$ terdapat adegan yaitu perang gagal. Perang gagal adalah perang tetapi di dalamnya belum ada titik akhir (rajapati). Dalam perang, pihak yang kalah mencari jalan atau kesempatan lain untuk melakukan perlawanan di waktu yang berbeda (Mudjanattistomo, 1977:164).

\section{Jejer III}

Bagian jejer III menurut Ki Sutarko biasanya hanya disajikan secara sepintas. Setelah itu akan dilanjutkan dengan adegan budhalan, merupakan adegan yang menggambarkan perjalanan suatu kelompok prajurit. 


\section{Patet Sanga}

Patet sanga merupakan bagian kedua dalam periode pembagian waktu pakeliran. Patet ini berlangsung dari pukul 24.00 sampai dengan pukul 03.00. Patet sanga terdiri dari Gara-gara dan Jejer IV.

Gara-gara

Gara-gara ini merupakan suatu adegan munculnya tokoh punakawan Semar, Gareng, Petruk dan Bagong. Dalam adegan ini punakawan akan mencairkan suasana dengan humor. Dalam adegan ini biasanya dalang membicarakan tentang kondisi sosial terkini di tengah masyarakat dengan kreativitasnya masing-masing.

Jejer IV

Bagian ini menceritakan tentang suatu tempat, biasanya sebuah pertapaan dengan seorang pertapa yang sedang memberi pengarahan pada kesatria untuk menyelesaikan permasalahan. Adegan selanjutnya adalah begalan/cakilan. Adegan begalan/cakilan ini dalam pakeliran gaya Surakarta disebut dengan perang kembang. Perang kembang merupakan perang antara kesatria dengan tokoh raksaksa (buta).

\section{Patet manyura}

Patet Manyura merupakan periode waktu yang ketiga dalam sajian pertunjukan wayang. Patet ini berlangsung dari pukul 03.00 sampai dengan pukul 06.00. Patet Manyura terdiri dari Jejer $V$ sampai Jejer VII.

Jejer $V$

Bagian ini menceritakan suatu kerajaan atau tempat lain yang berhubungan dengan permasalahan dan mulai dicari solusi penyelesaiannya. Setelah itu akan dilanjutkan dengan rangkaian adegan perang.

Jejer VI

Di bagian ini permasalahan yang muncul dari jejer I bisa dipecahkan dan diselesaikan. Jejer VII

Bagian ini merupakan adegan dalam suatu negara yang telah berhasil menyelesaikan permasalahan. Dalam adegan ini diucapkan rasa syukur kepada Tuhan atas semua nikmatnya. Setelah itu pertunjukan wayang akan diakhiri dengan tancep kayon.

Menurut Sutarko (2011) pembagian jejer dan adegan dalam pakeliran gaya Kedu Bagelen banyak mengacu pada pakeliran gaya Surakarta. Pakeliran gaya Kedu Bagelen itu memiliki wadah Yogyakarta tetapi isinya Surakarta.

\section{Gending-Gending dalam Penyajian Karawitan Pakeliran Gaya Kedu Bagelen}

\section{Gending Pengawe-awe}

Ladrang Sekar Gadhung Laras Slendro Patet Manyura

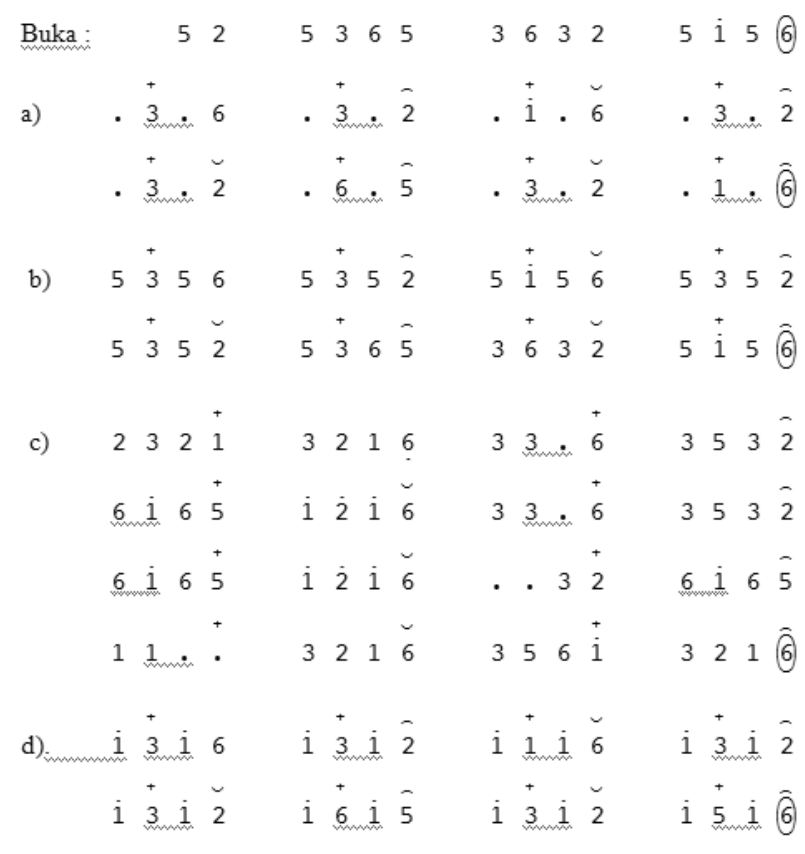

Ladrang Sekar Gadhung Laras Slendro Patet Manyura ini disajikan dalam irama I (tanggung), irama II (dados) dan irama III (wiled) yang diawali dari buka bonang katampen kendang menggunakan kendang kalih. Pada awalnya Ladrang Sekar Gadhung dalam karawitan pakeliran Gaya Kedu Bagelen disajikan menggunakan kendang batang, akan tetapi seiring perkembangannya, sekarang telah menggunakan kendang kalih.

Irama I disajikan beberapa kali dirangkai dengan garap kendhangan kebar dan kendhangan rumpakan secara bergantian. Setelah itu transisi/ menuju ke garap irama II atau bagian (b). Bagian ini menggunakan pola kendhangan ladrang irama II kendang kalih yang dirangkai dengan garap kendhangan tayuban secara bergantian. Pada bagian (b) ini garap balungan menggunakan garap balungan pancer nada 5. Selanjutnya diteruskan 
dengan sajian irama III (ndawah) dengan kendhangan ciblon. Di akhir sajian setelah irama III akan kembali ke irama I bagian (d). Bagian ini garap penyajiannya soran sampai suwuk atau berhenti.

\section{Gending Gagalan (uyon-uyon)}

Bagian gending gagalan dalam karawitan pakeliran gaya Bagelen tidak memiliki gending baku, tetapi gending-gending yang disajikan adalah gending ketuk 2 kerep minggah ketuk 4 kerep laras slendro patet sanga. Dalam penelitian ini diambil contoh gending Gambir Sawit Laras Slendro Patet Sanga. Buka:

Gending Gambir Sawit Laras Slendro Patet Sanga

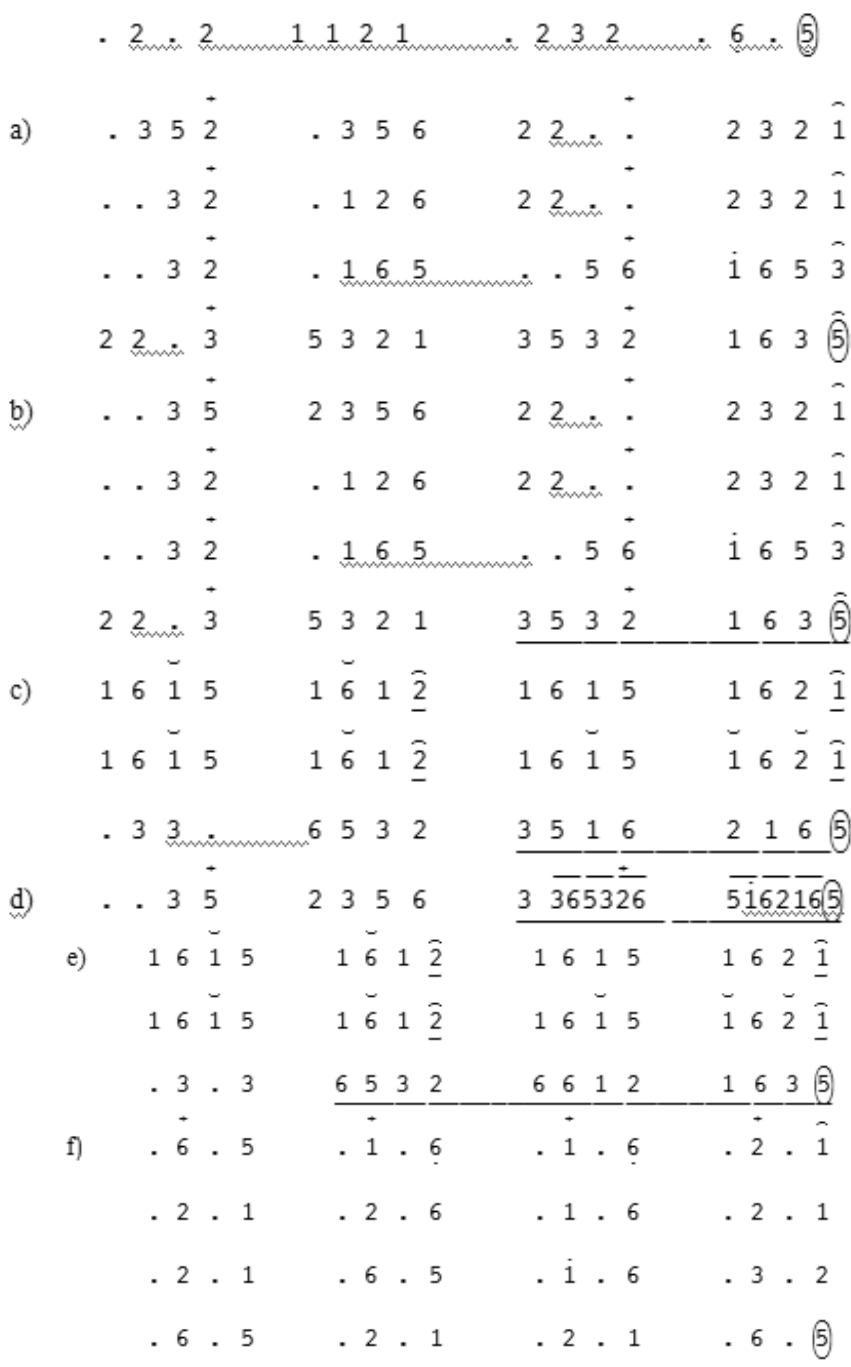

Sajian gending Gambir Sawit Laras Slendro Patet Sanga diawali dari buka gender, setelah buka katampen kendang batang kendhangan kosek gending. Kemudian gending akan menuju bagian (a) dilanjutkan ke bagian (b). Pada bagian (b) terjadi transisi menuju ke garap kebaran atau (c), tepatnya sebelum gong atau pada gatra ke15 dan 16 (ditandai dengan tanda garis bawah). Pada bagian (c) di akhir gatra terjadi transisi lagi untuk menuju bagian gending (d) dengan abaaba kendang. Tempat transisi ditandai dengan garis bawah. Sajian gending akan kembali lagi ke bagian (c) disajikan satu ulihan. Sama seperti sajian sebelumnya, gending bagian (c) hanya disajikan satu ulihan kemudian menuju ke bagian (d). Tempat transisi ditandai dengan garis bawah. Selanjutnya menuju ke bagian kebaran lagi atau bagian (e) dirangkai dengan transisi perpindahan menuju bagian ndawah atau bagian (f). Bagian ndawah ini bisa disajikan berulang-ulang sesuai 61 elengan kebutuhan.

3. Gending untuk Jejer I (Patet Nem) Ayak-ayak Panjang Mas Laras Slendro Patet Nem

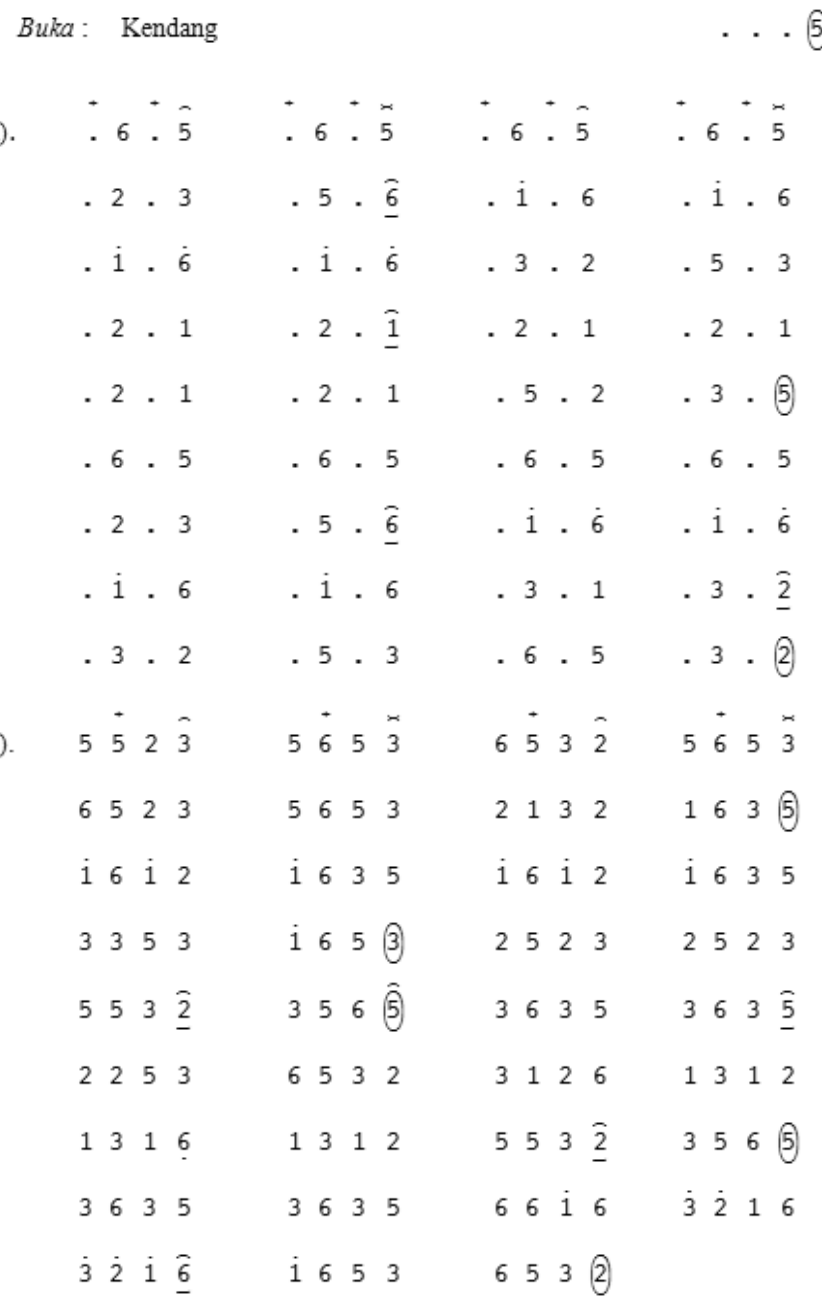

Gending Ayak-ayak Panjang Mas Laras Slendro Patet Nem bagian a disajikan hanya satu 
kali/satu ulihan diawali dari aba-aba dhodhogan kotak oleh dalang kemudian katampen kendang batang garap irama I. Transisi ke irama II berada pada gatra ke-19 dan 20. Ayak-ayak bagian ini disajikan untuk iringan pada saat bedhol kayon atau awal dimulainya pertunjukan wayang.

Gending Ayak-ayak Panjang Mas Laras Slendro Patet Nem pada bagian b dapat disajikan beberapa ulihan sesuai kebutuhan dalang/wayang. Bagian ini disajikan menggunakan kendang batang garap pinatut (menirukan solah/gerak wayang). Peralihan menuju srepeg menunggu setelah ada aba-aba dari dalang melalui dhodhogan. Waktu peralihan atau transisi pada saat menjelang gong suwukan atau gong ageng.

\section{Srepeg laras slendro patet nem}

b). $L i k I$

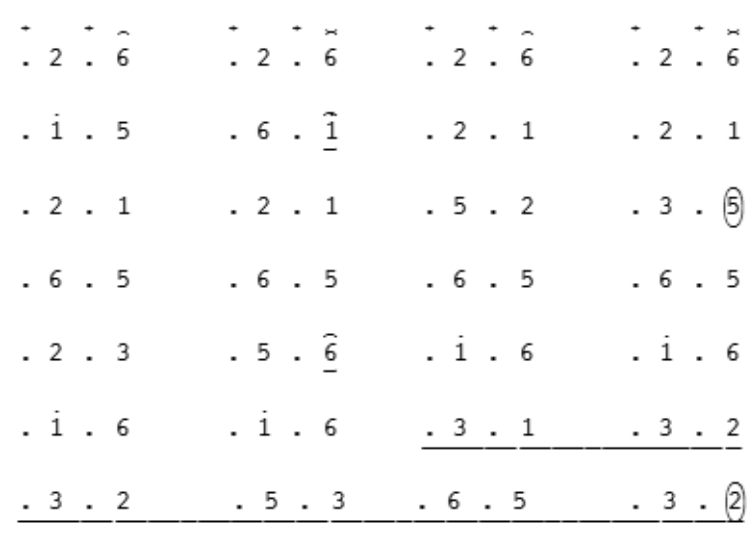

Srepeg bagian a) lik I disajikan hanya satu ulihan dengan garap irama I. Setelah satu ulihan akan kembali lagi ke Ayak-ayak Panjang Mas bagian b dengan garap irama II. Perpindahan irama/transisi terjadi pada gatra ke-23 sampai dengan gatra ke26 atau pada gatra yang diberi tanda garis bawah. b). Lik II

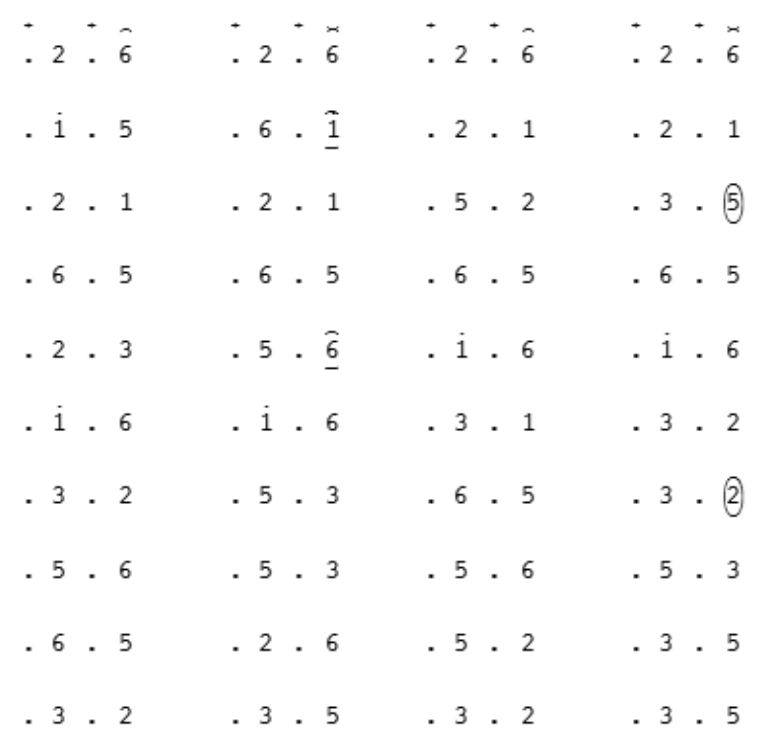

Srepeg bagian b) lik II ini hanya disajikan satu ulihan, srepeg bagian ini digunakan sebagai transisi/peralihan menuju gending Karawitan Bagelen Ketuk 2 Kerep Laras Slendro Patet Nem.

Gending Karawitan Bagelen Ketuk 2 Kerep Laras Slendro Patet Nem.

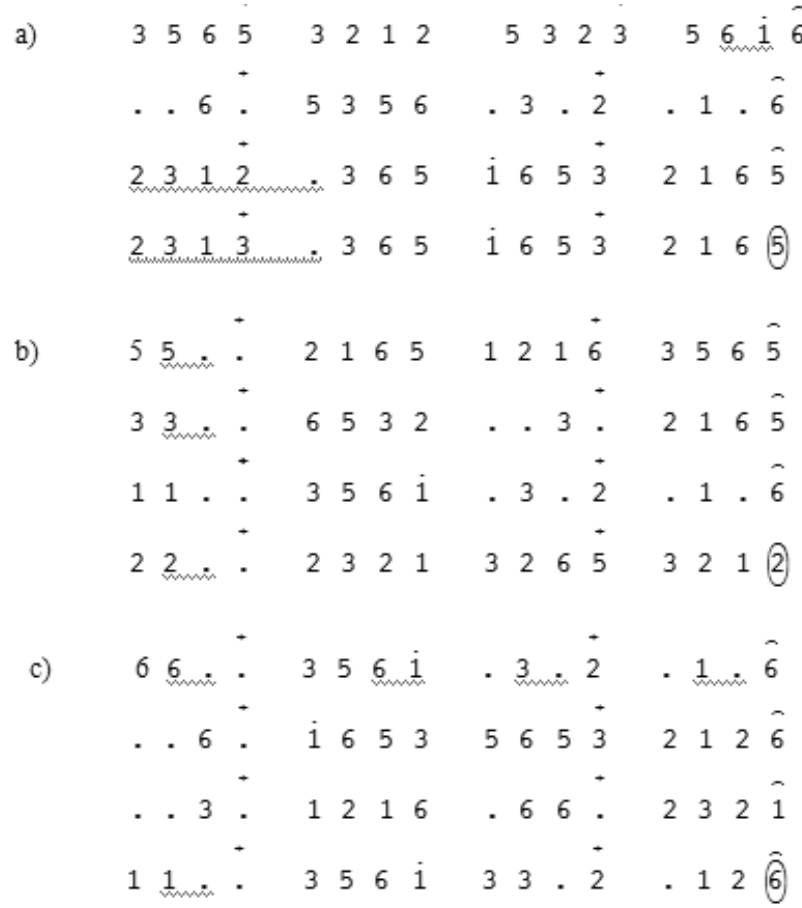


d)

\begin{tabular}{|c|c|c|c|c|c|c|c|c|c|c|c|}
\hline 356 & 5 & 2 & 12 & 26 & & 5 & & 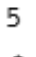 & & & 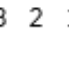 \\
\hline 1. & . & 3 & 56 & $6 i$ & & 3 & & 2 & & 1 & \\
\hline 6. & 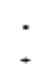 & 6 & $\begin{array}{ll}6 & 1\end{array}$ & 12 & 5 & 3 & 2 & 1 & & 5 & 52 \\
\hline & & 2 & 16 & 65 & 2 & & & & & & \\
\hline
\end{tabular}

e)

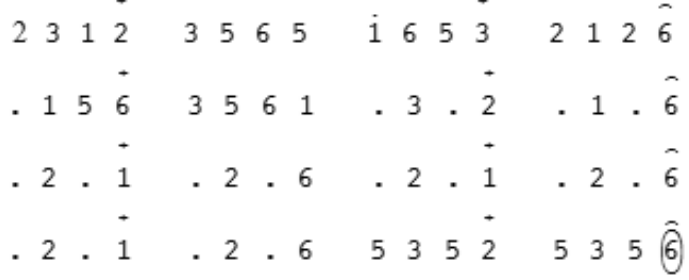

Gending Karawitan Bagelen Laras Slendro Patet Nem ini digunakan sebagai iringan saat dalang njantur. Pada gong pertama atau bagian a garap sajian adalah irama I. Sebelum kenongan ke-1 dalang memberi aba-aba untuk garap sirep sekaligus sebagai transisi ke irama II. Setelah gong pertama atau di bagian b garap sajiannya menggunakan garap irama II (dados). Bagian e digunakan sebagai transisi menuju ke Ladrang Karawitan Bagelen. Garap kendhangan untuk gending ini menggunakan kendhangan kosek gending. Gending karawitan Bagelen ini hanya disajikan satu ulihan menurut kebutuhan. Apabila belum selesai bagian $d$ tetapi dalang sudah memberikan aba-aba (dhodhogan) maka gending langsung menuju ke bagian e sebagai transisi untuk menuju ke ladrang karawitan Bagelen.

\section{Ladrang Karawitan Bagelen Laras Slendro Patet Nem.}

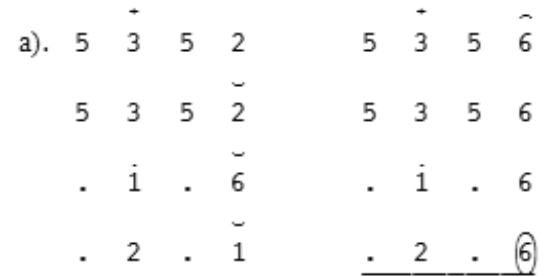

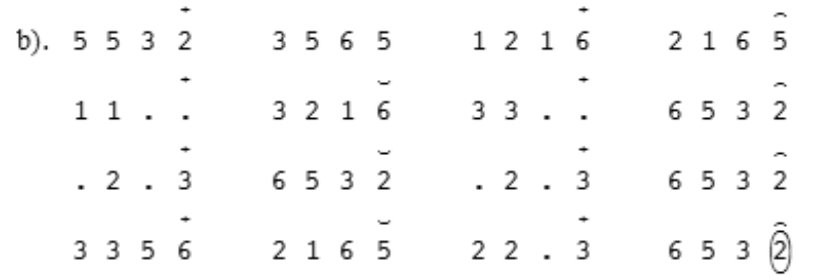

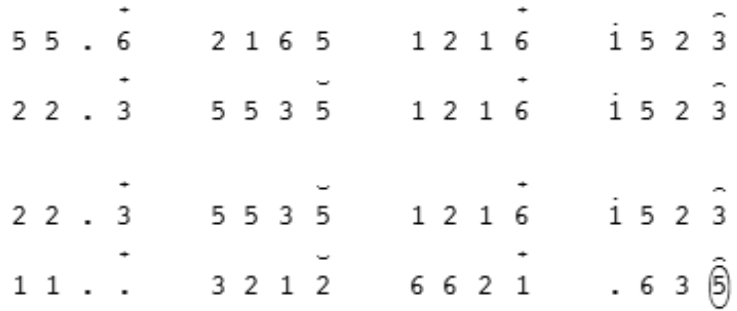

Ladrang Karawitan Bagelen merupakan satu rangkaian dengan gending Karawitan. Ladrang Karawitan bagian a disajikan dalam irama I dan II sekaligus merupakan bagian untuk transisi menuju garap gending berikutnya. Pada gatra terakhir yang diberi tanda garis bawah, digunakan sebagai transisi menuju ke garap irama III. Ladrang ini hanya disajikan satu ulihan kemudian suwuk.

4. Kondur Kedhaton/Kedhatonan.

Ladrang Moncer Laras Slendro Patet Manyura

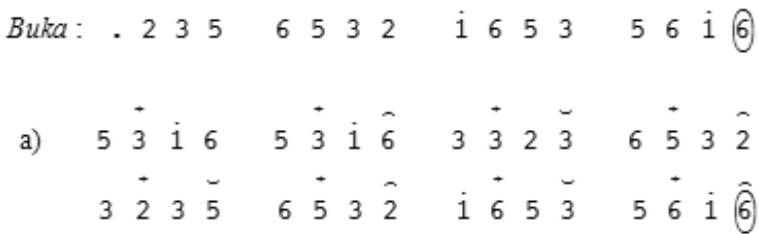

b). Ngelik.

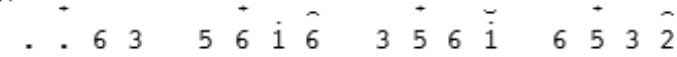

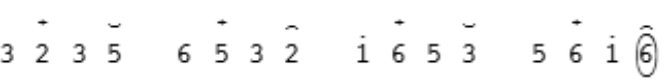

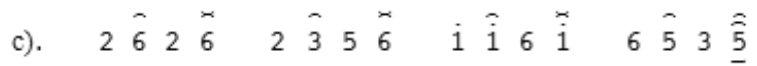

$$
\begin{aligned}
& \begin{array}{llllllllllllllll}
6 & 2 & 3 & 5 & 6 & 2 & 3 & 5 & 3 & 3 & 2 & 1 & 6 & 1 & 2 & 3
\end{array} \\
& \begin{array}{llllllllllllllll}
6 & 2 & 3 & 5 & 6 & 2 & 3 & 5 & 1 & 1 & 3 & 2 & 6 & 3 & 5 & 6
\end{array} \\
& \text { a) } .26 .626 .6165 .1 .6
\end{aligned}
$$

Ladrang Moncer disajikan untuk mengiringi adegan kundhur kedhaton. Diawali dalang mengucapkan sasmita gending atau aba-aba meminta gending seperti "yen cinandra katon nggendarah koncane", buka bonang kemudian katampen kendang batang kendhangan kosek ladrang irama I. Bagian a disajikan satu ulihan kemudian ke bagian ii/ngelik. Bagian ngelik hanya disajikan satu ulihan kemudian kembali ke bagian umpak. Pada ulihan ke dua (lik) dijadikan sebagai transisi menuju garap irama II. Transisi dilakukan setelah gong atau pada kenong pertama tetapi sebelum gong, garap irama sudah mulai terjadi perpindahan. Setelah sajian irama II menuju ke garap irama I sekaligus sebagai transisi ke gending bentuk srepeg c.

Bagian srepeg ini disajikan dalam garap irama $I$ dan berulang-ulang sesuai dengan kebutuhan. Di akhir sajian dirangkai dengan bagian d dengan garap tabuhan ngracik. Bagian ini hanya disajikan satu ulihan karena sebagai tanda untuk berhenti atau suwuk. 
5. Jejer II (Gagah).

Ladrang Mandraguna Laras Pelog Patet Nem.

Buka

$\begin{array}{llllllllll}: & 5 & 2 & 3 & 5 & 5 & 4 & 2 & \text { : } \\ 53 & 56 & 2 & 1 & 6 & 5 & 2 & 3 & 5 & 6\end{array}$

Bagian jejer II tokoh gagah ini menggunakan gending Ladrang Mandraguna Laras Pelog Patet Nem. Diawali permintaan dalang melalui sasmita gending seperti "narendra kang digdaya sekti mandraguna", kemudian buka bonang katampen kendang dan instrumen lainnya. Ladrang ini disajikan dalam garap irama I dan II. Irama I disajikan dua ulihan dengan garap soran. Pada ulihan yang ketiga atau setelah gong kedua dijadikan sebagai transisi perpindahan menuju irama II, digunakan sebagai iringan dalang melakukan janturan, sehingga gending disajikan dengan garap sirep. Setelah selesai janturan, garap menuju ke irama I lagi dan diakhiri dengan suwuk gropak atau cepat.

6. Jejer III (Patet Nem).

Playon Lasem Bagelen Laras Slendro Patet Nem.

Buka: Kendang ...

a)

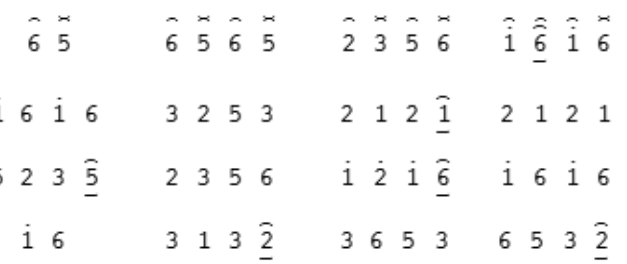

b)

$\begin{array}{llllllllllllllll}5 & 6 & 5 & 3 & 1 & 6 & 5 & 3 & 6 & 5 & 2 & 6 & 5 & 2 & 3 & \frac{5}{5} \\ 3 & 2 & 1 & 2 & 6 & 1 & 2 & \hat{3} & 5 & 6 & 1 & 6 & 5 & 2 & 3 & \frac{5}{5} \\ 1 & 6 & 5 & 3 & 2 & 1 & 3 & \hat{2} & 6 & 6 & 1 & 2 & 3 & 5 & 6 & 5 \\ 2 & 3 & 2 & 1 & 2 & 1 & 3 & 2 & 5 & 6 & i & \overline{6} & 3 & 2 & 6 & 3 \\ 6 & 5 & 3 & 2\end{array}$

Suwuk:

$$
\begin{array}{llllll}
1 & 1 & 3 & 2 & 1 & 6
\end{array}
$$

Jejer III dalam pakeliran gaya Bagelen umumnya hanya disajikan secara sepintas dengan menggunakan iringan Playon Lasem Bagelen garap sirep (Wawancara dengan Ki Hartono tanggal 30 Maret 2012. Playon ini digunakan juga sebagai iringan adegan-adegan lain dalam patet nem seperti adegan paseban njawi dan perang gagal.

Sajian Playon Lasem Bagelen diawali dengan aba-aba dalang atau dhodhogan kemudian dilanjutkan oleh ater-ater kendang sebagai buka. Pola kendhangan yang digunakan adalah kendhangan pinatut atau disesuaikan/ menyesuaikan dengan gerakan wayang. Playon Lasem Bagelen bagian a disajikan hanya satu ulihan. Bagian $b$ disajikan berulang-ulang sesuai dengan kebutuhan. Suwuk berada pada setiap gongan sesuai dengan ater-ater suwuk kendang berdasarkan isyarat dari dalang.

7. Adegan Gara-gara (Patet Sanga).

Ayak-ayak Bagelen Laras Slendro Patet Sanga. Buka :

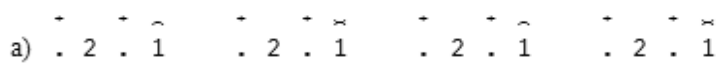

$$
\begin{aligned}
& 5 \cdot 5 \cdot 6 \cdot \frac{1}{1} \cdot 5 \cdot 6 \cdot 1 \cdot 2 \\
& .3 .5 .6 .5 \quad 6.5 .6 .5 \\
& .6 .5 \quad .6 .5 \quad .2 .3 \quad .5 .6 \\
& \begin{array}{llllllllllllllll}
2 & 1 & 5 & 3 & 2 & 3 & 5 & 6 & 2 & 1 & 5 & 3 & 2 & 3 & 5 & 6
\end{array} \\
& \begin{array}{llllllllllll}
2 & 1 & 3 & 2 & 6 & 1 & 2 & 3 & 0 & 5 & 5
\end{array} \\
& \text { i } 6233 \quad 56355 \quad \text { i } 6223 \quad 563 \underline{5} \\
& \text {. } 2.1 \quad \cdot 2 \cdot 1 \quad 5651 \quad 5321 \\
& .6 \cdot 5 \cdot 2 \cdot 1 \quad \cdot 6 \cdot 5 \quad \cdot 2 \cdot \frac{1}{1} \\
& \text {. } 2.2 \quad 3.2565 \text { i } 5216 \\
& \cdot 2 \cdot 3 \quad \cdot 2 \cdot 1 \quad \cdot 2 \cdot 3 \quad \cdot 2 \cdot \frac{1}{1} \\
& \text {. } 2.2556 \text { i } \overline{56} i \quad 5 \quad 2 \quad 532 \text { (1) }
\end{aligned}
$$




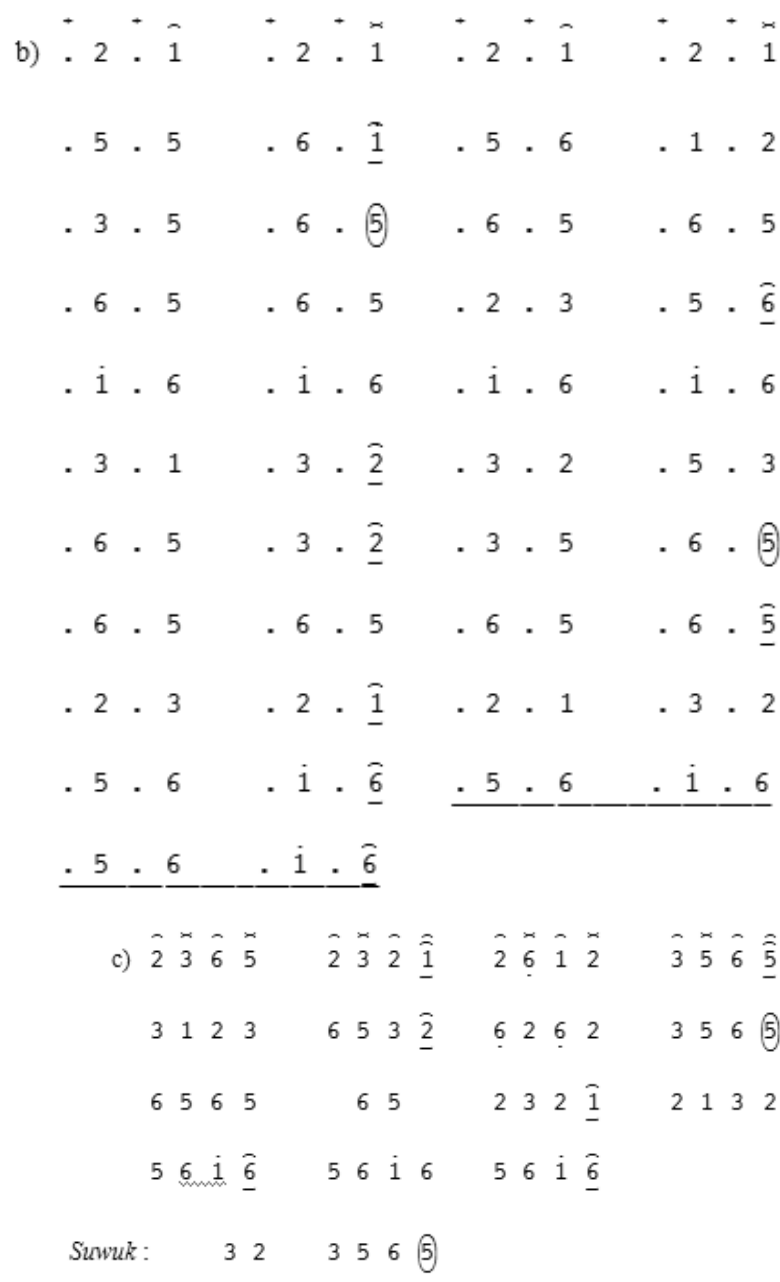

Ayak-ayak Bagelen memiliki tiga bagian bentuk gending yang disajikan secara kesinambungan, yaitu bagian a bentuk ayak-ayak, bagian b bentuk srepeg dan bagian c adalah bentuk playon. Fungsi gending ini adalah sebagai iringan menjelang gara-gara.

Ayak-ayak Sanga Bagelen diawali dari dhodhogan kotak oleh dalang kemudian dilanjutkan oleh ater-ater kendang sebagai buka. Gending bagian a atau ayak-ayak disajikan dalam garap irama I sebanyak satu ulihan. Bagian gending b atau srepeg juga disajikan satu ulihan dengan trasisi perpindahan ke playon/bagian c pada gatra ke-21. Sajian selanjutnya dilanjutkan gending bentuk playon/bagian c disajikan berulang-ulang sesuai dengan kebutuhan.

8. Playon Sanga Jangkep Bagelen Laras Slendro Patet Sanga.
Buka :

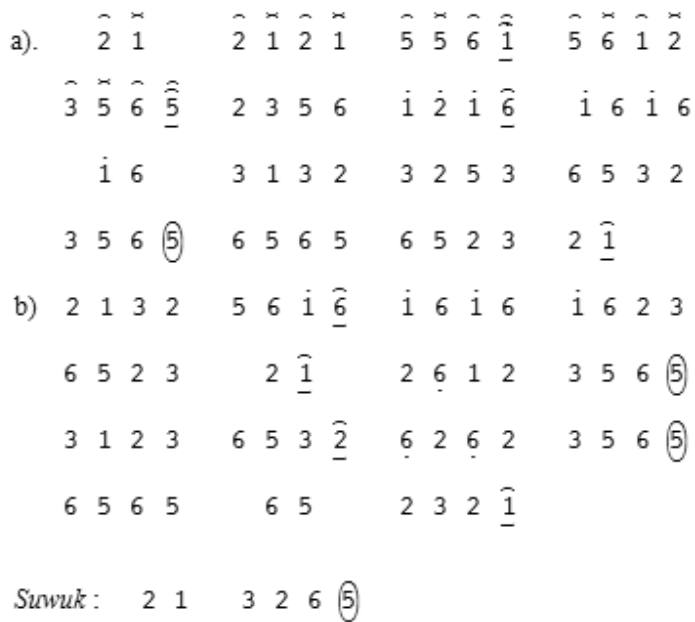

Playon Sanga Jangkep Bagelen disajikan untuk mengiringi adegan cakilan/begalan (perang kembang) dan adegan-adegan dalam patet sanga. Sajian Playon Jangkep ini diawali dari aba-aba dalang melalui dhodhogan kemudian dilanjutkan buka playon oleh kendang batang. Playon disajikan dalam irama I kendhangan pinatut mengikuti gerak wayang. Bagian a hanya disajikan satu ulihan, sedangkan bagian b disajikan beberapa ulihan sesuai dengan keperluan. Suwuk dilakukan di setiap gong ageng atau gong suwukan sesuai dengan aba-aba dari dalang.

9. Gagak Urak atau Playon Srambahan Laras Slendro Patet Manyura.

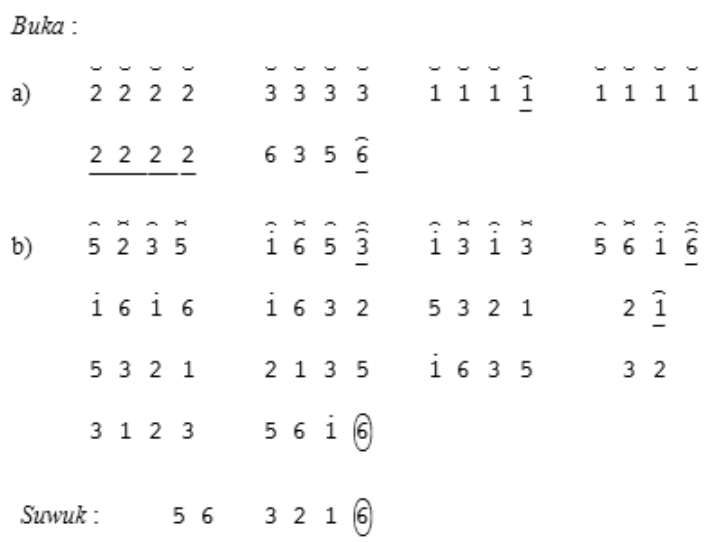

Gagak Urak disajikan dalam patet manyura di awal dan hanya satu kali sajian saja. Playon Srambahan atau Gagak Urak penyajiannya diawali dhodhogan kotak oleh dalang kemudian dilanjutkan ater-ater kendang sebagai buka menggunakan kendang batang. Pola kendhangan yang digunakan adalah pola kendhangan pinatut menyesuaikan gerak wayang. Gagak Urak pada 
bagian a disajikan satu ulihan saja. Bagian b disajikan secara berulang-ulang sesuai dengan kebutuhan. Suwuk dilakukan setelah gong ageng atau gong suwukan dengan aba-aba kendang setelah ada sasmita atau tanda berhenti dari dalang.

10. Playon Manyura Bagelen Laras Slendro Patet Manyura.

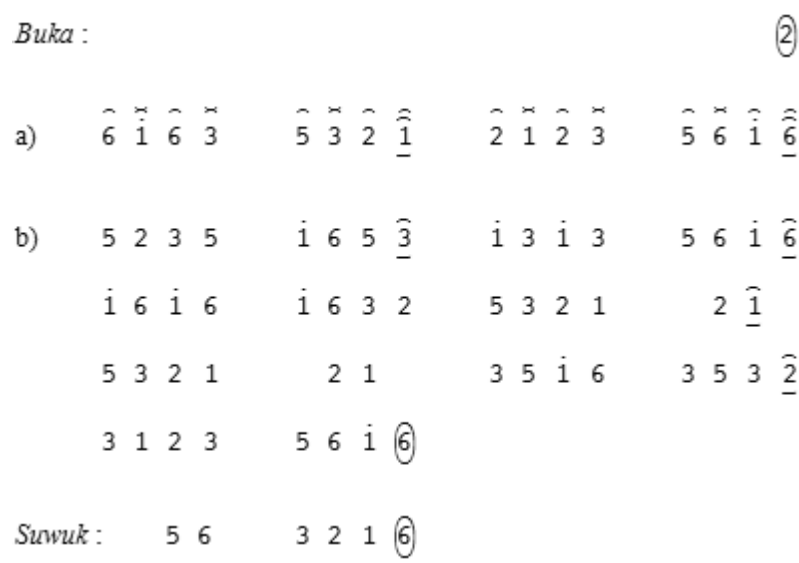

Playon Manyura Bagelen ini disajikan untuk iringan adegan-adegan yang ada di patet manyura. Playon ini dimulai dari dhodhogan kotak oleh dalang kemudian dilanjutkan dengan ater-ater kendang sebagai buka menggunakan kendang batang. Pola kendhangan adalah kendhangan pinatut sesuai dengan gerak wayang. Pada bagian a hanya disajikan satu ulihan sedangkan bagian $\mathrm{b}$ disajikan berulang-ulang menurut kebutuhan. Suwuk dilakukan setelah gong ageng atau gong suwukan kendang berdasar pada aba-aba dalang.

11. Playon Tanggung Bagelen Laras Slendro Patet Manyura.

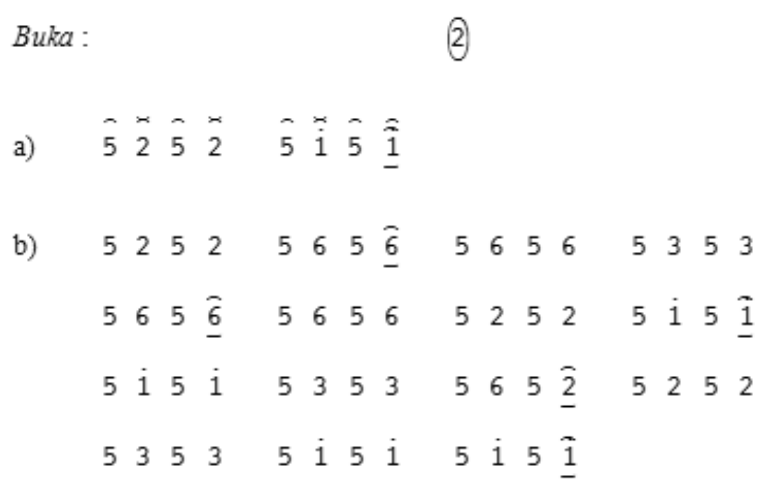

Suwuk:

$$
\text { . } 52
$$

Playon Tanggung ini dalam patet manyura disajikan untuk mengiringi adegan perang Brubuh. Diawali dari dhodhogan kotak kemudian dilanjutkan ater-ater kendang sebagai buka. Kendang yang digunakan kendang batang kendhangan pinatut sesuai dengan gerakan wayang.
Bagian (a) dilakukan hanya satu ulihan sedangkan bagian (b) dilakukan berulang-ulang sesuai dengan kebutuhan. Suwuk dilakukan setelah gong ageng atau gong suwukan oleh kendang berdasar ater-ater suwuk dari dalang.

12. Sampak Manyura Bagelen Laras Slendro Patet Manyura.
Buka :

a)

b)

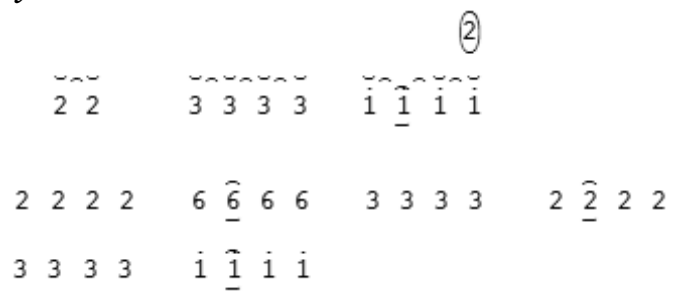

Gending ini disajikan untuk mengiringi adegan perang paling akhir dalam patet manyura. Sampak diawali dari dhodhogan kotak dalang diteruskan ater-ater buka oleh kendang selanjutkan diteruskan dengan istrumen lain. Bagian (a) hanya disajikan satu ulihan sementara bagian (b) disajikan berulang-ulang sesuai dengan kebutuhan.

\section{Penutup}

Karawitan pakeliran merupakan sajian karawitan yang berfungsi sebagai iringan dalam sebuah pertunjukan wayang. Sebagai musik iringan, karawitan pakeliran membantu terciptanya suatu adegan serta memperjelas karakter tokoh wayang melalui sajian gendinggending pakeliran dari awal jejer I sampai dengan akhir pertunjukan atau tancep kayon.

Dalam pakeliran terdapat beberapa gaya serta memiliki ciri khusus tersendiri. Ciri tersebut menjadi sebuah identitas yang membedakan antara gaya pakeliran daerah satu dengan daerah lain. Gaya-gaya pakeliran tersebut di antaranya adalah gaya Yogyakarta, gaya Surakarta, gaya Banyumas, gaya Pesisir dan gaya Kedu. Gaya Kedu sendiri masih dibagi lagi menjadi beberapa gaya di antaranya gaya Kedu Magelang, Kedu Wonosobo, Kedu Temanggung dan Kedu Bagelen atau Purworejo.

Pakeliran gaya Kedu Bagelen merupakan gaya pakeliran yang berkembang di tengah masyarakat Purworejo, tetapi persebarannya tidak berkembang seperti pakeliran gaya Yogyakarta maupun Surakarta. Pakeliran gaya Yogyakarta dan Surakarta lebih diterima masyarakat dibanding dengan gaya Kedu Bagelen, karena dua gaya ini 
mampu berkembang dan menyesuaikan dengan perkembangan jaman. Meskipun pakeliran gaya Kedu Bagelen merupakan sebagian kecil dari gaya pakeliran di Jawa, ternyata memiliki spesifikasi dalam karawitan pakeliran. Spesifikasi tersebut terdapat dalam struktur penyajian gending iringan dari awal pertunjukan sampai akhir serta garap gending-gending di dalamnya. Penyajian gendinggending dalam pakeliran Bagelen diawali dengan gending pengawe-awe dan gending gagalan sebagai sajian sebelum pertunjukan wayang dimulai. Kemudian dalam pertunjukan wayang, gending yang disajikan sangat beragam dimulai dari sajian Ayak-ayak Panjang Mas Laras Slendro Patet Nem sampai dengan Sampak Manyura Bagelen Laras Slendro Patet Manyura.

Garap dalam karawitan pakeliran gaya Kedu Bagelen terdapat ciri khusus yang terdapat dalam garap tabuhan balungan/instrumen, ater-ater buka oleh kendang serta garap-garap lainnya. Karawitan pakeliran gaya Kedu Bagelen memiliki susunan balungan gending sendiri. Begitu juga dengan aterater buka, karawitan gaya Kedu Bagelen memiliki spesifikasi tersendiri dan berbeda dengan gaya lain.

\section{Kepustakaan}

Hastanto, Sri. 2009. Konsep Patet Dalam Karawitan Jawa. Surakarta: ISI Press.

Kayam, Umar. 2001. Kelir Tanpa Batas. Yogyakarta: Gama Media.

Martopangrawit. 1975. Pengetahuan Karawitan I. Surakarta: ASKI.

Mudjanattistomo, R.M., dkk. 1977. Pedalangan Ngayogjakarta. $\quad$ Yogyakarta: Yayasan Habirandha.

Murtiyoso, Bambang. 2004. Pertumbuhan dan Perkembangan Seni Pertunjukan Wayang. Surakarta: Citra Etnika.
Purwoko, Gunawan. 2010. "Karawitan Pakeliran Gaya Kedu Temanggungan”[Skripsi] S-I Jurusan Seni Karawitan Fakultas Seni Pertunjukan Institut Seni Indonesia Yogyakarta.

Singarimbun, Masri dan Sofian Efendi. 1989. Metode Penelitian Survai. Jakarta: LP3ES.

Purwadi. 2006. Seni Karawitan Jawa: Ungkapan Keindahan dalam Musik Gamelan. Yogyakarta: Hanan Pustaka.

Soetarno. 2002. Pakeliran Pujo Sumarto, Narto Sabdo, dan Pakeliran Dekade 1996-2001. Surakarta: STSI Press.

Sumarsam. 2002. Hayatan Gamelan: Kedalaman Lagu Teori dan Perspektif. Surakarta: STSI Press.

Supanggah, Rahayu. 2002. Bothekan Karawitan I. Jakarta: Masyarakat Seni Pertunjukan Indonesia. 2009. Bothekan Karawitan II: Garap. Surakarta: ISI Press.

Yudoyono, Bambang. 1983. Gamelan Jawa: Awal Mula Makna Masa Depannya. Jakarta: PT Karya Unipress.

\section{Informan}

Ki Sutarko Hadi Wacono (65 tahun), dalang wayang kulit gaya Yogyakarta, Surakarta dan gaya Kedu Bagelen, dari Desa Pacor Kecamatan Kutoarjo.

Ki Hartono (59 tahun), dalang wayang kulit gaya Yogyakarta, gaya Kedu Bagelen dan pengrawit, dari Desa Klepu Kecamatan Butuh.

Ki Parto Slamet (62 tahun), pengrawit dari Desa Pituruh, Kecamatan Pituruh.

Ki Suparno (56 tahun), dalang wayang kulit gaya Yogyakarta dan pengrawit, dari Desa Kaligono, Kecamatan Kaligesing. 